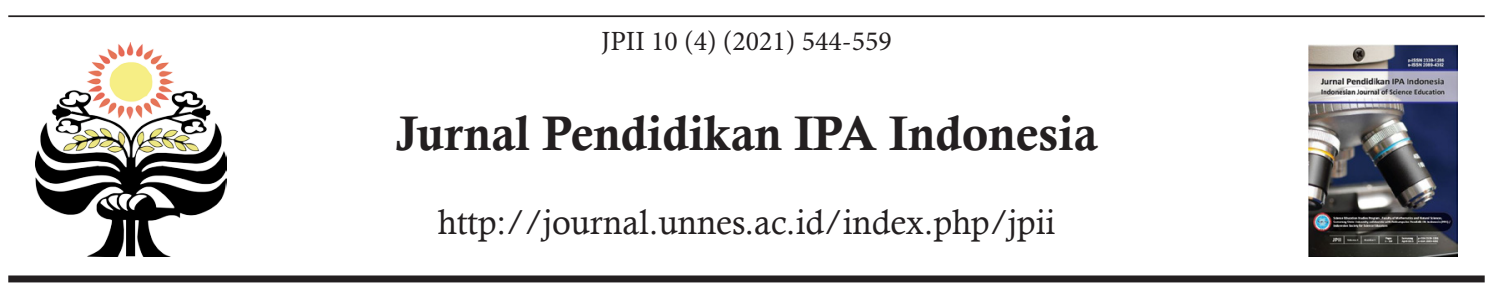

\title{
NATURAL SCIENTIFIC THINKING IN FOREIGN STUDENTS OF PRE-UNIVERSITY COURSES IN THE CONTEXT OF INTEGRATION INTO THE RUSSIAN EDUCATIONAL ENVIRONMENTS
}

\author{
O. Fisenko ${ }^{* 1}$, V. Nikitina ${ }^{2}$, T. Satina ${ }^{3}$ \\ ${ }^{1,2}$ Peoples' Friendship University of Russia (RUDN University), Moscow, Russian Federation \\ ${ }^{3}$ Financial University under the Government of the Russian Federation, Moscow, Russian Federation
}

DOI: 10.15294/jpii.v10i4.31741

Accepted: August 26 ${ }^{\text {th }} 2021$. Approved: December 27 $7^{\text {th }} 2021$. Published: December $31^{\text {st }} 2021$

\begin{abstract}
This article is the result of a two-year-long experiment conducted by the authors. The purpose of the research was to study the natural scientific thinking of foreign students of preparatory departments in the context of integrative processes. The quantitative and qualitative analysis of the regulatory framework governing the educational process at the stage of pre-university training, including syllabi and steering documents of faculties of pre-university training, formed the methodological basis of the research. The modified criteria-focused TEM-11 test was used as a diagnostic tool. The method of expert evaluations ensured the reliability and validity of the research. The study provided evidence of the feasibility of including an integration course in "biophysics" along with biology, physics, and chemistry in the curricula of preparatory departments that prepare foreign students for admission to medical, agricultural, veterinary, and biological faculties. It does not appear reasonable to include an online course in the training system for foreign students who are residents since they already developed the differential-synthetic and synthetic stages of natural scientific thinking while they were learning the trade. It is concluded that the Biophysics integrative online course studied by foreign students of faculties of pre-university training, develops a special type of natural scientific thinking, which will be the basis for framing professional thinking in the future. A total of 374 people took part in the experiment (188 people were included in the experimental group and 186 people became part of the control group). The comparative analysis of the stages of development of natural scientific thinking in the control and experimental groups showed significant progress in the experimental group. After the experiment, the number of respondents at the common empirical stage of development of natural scientific thinking was $11.2 \%$ of the entire sample; the number of respondents at the scientific empirical stage was $32.8 \%$, at the synthetic differential stage $-44.7 \%$ and at the synthetic stage $-27.6 \%$.
\end{abstract}

(C) 2021 Science Education Study Program FMIPA UNNES Semarang

Keywords: scientific thinking; pre-university training; Biophysics integrative online course

\section{INTRODUCTION}

A radical revision of the existing programs is required to integrate Russian education into the common European educational environment. The coronavirus pandemic that took over the entire world in early 2020, complicates the integrative processes. Amidst the coronavirus pandemic, the advancement of e-learning and

*Correspondence Address

E-mail: olfiss@list.ru online technologies is becoming a distinctive feature of the modern educational paradigm. Traditional approaches to education are not always applicable in the context of the formation of a multicultural personality, and new technologies are only developing. Their advancement in the field of e-learning and online education results in transformation of the structure and content of the Russian education system: new educational standards are being approved, a new system for assessing learning outcomes is being introduced. 
The Russian education system is designed to focus on the needs of students and create optimal conditions for the development and education of highly qualified specialists who have mastered their professional expertise perfectly. Under these circumstances, the system of pre-university training of foreign students of natural and biological faculties is of particular importance. Online education of future doctors, biologists, agronomists, veterinarians are associated with a number of difficulties related to the need to master the preparatory department program quickly, as well as the development of a special way of thinking among foreign students allowing them to successfully master the main educational program.

The conducted analysis of scientific research literature on the study topic shows that important steps have been taken in the study of the aspects of natural scientific thinking, but many of the proposed theses lack experimental data, and the available empirical research was carried out on a small number of subjects. Pedagogical and organizational, representatives of these approaches proceed from the need to develop natural scientific thinking in the process of educational and pedagogical activities, starting from kindergarten and ending with the period of professional development (if we are talking about teachers).

The works of Broks (2014) and Das (2014) have contributed to the development of stages and criteria of scientific thinking in the process of educational activities, however, these works lack empirical data confirming the initial research hypotheses in practice. The crisis of natural science education is related to the fact that its tasks, goals, and methods do not meet the needs of the modern society characterized by a breakthrough of information technology in all spheres of activity. The aspects of the global landscape and the world view which have developed under the influence of post-non-classical science, do not correlate with the theoretical and methodological principles and attitudes of post-non-classical science, with the new type of rationality discovered by it. Accordingly, the modern education system is not able to train specialists capable of solving current problems that are becoming ever more global and multidimensional.

Speaking of educational scientific research (ESR), Broks (2014) concludes that the educational process must include studying the content and methodology of fundamental and applied scientific research. The disadvantage of the pedagogical process is the focus on memorizing important knowledge and studying formal algorithms for their proper application in practice. Educators must pay attention to special studies of scientific research methods. They should teach how to gain relevant knowledge (basic science) and apply it (applied science) to meet our needs. Das (2014) describes the need to develop scientific thinking in order to develop science resources and free society from the plague of superstitions, prejudices, inertia, and so forth. From the point of view of the researcher, the result of scientific thinking is the productivity of something specific, which is achieved by a conscious synthesis of facts.

Taber (2012), Taber et al. (2016), and Klahr et al. (2019) see natural science education as a necessary condition for the development of natural scientific thinking. Natural science teaching should describe the nature and status of various ideas to help students fully appreciate the creative and rational aspects of science. In order to improve natural science education, we must improve the quality and versatility of answers to the two related questions: what is scientific thinking? how to teach it? The NOS aspect focused on the role of models and analogies in scientific research. The modules described offering a general approach that can be used to develop a curriculum based on the synergy between teaching NOS and specific scientific topics.

Continuing the scientific research, Murtonen \& Salmento (2019) note that scientific thinking is formed during higher education combining many important theoretical aspects of thinking skills. The components of this broad scientific thinking are: 1) critical thinking and understanding of the foundations of science; 2) epistemic understanding; 3) research skills; 4) fact-based reasoning skills; and 5) contextual understanding. The undertaken research provides a basis for the development of higher-order thinking skills during higher education.

Practical experience in scientific thinking development during educational activities is described in the works of Klahr et al. (2019); Koerber \& Osterhaus (2019); and Purnami et al. (2021). Koerber \& Osterhaus (2019) chose early scientific thinking in children attending preschool institutions as the object of scientific research. Based on the developed 30-element tool (Science-K inventory), it was examined whether the individual differences between the three components of scientific thinking (experimentation, data interpretation, and understanding of the nature of science) in children are stable, whether information processing skills (intelligence, language skills) in children and the development of an advanced theory of mind are increased, and whether individual differences in scientific thinking predict individual differences in knowledge about the scientific content. 
The works of Klahr et al. (2019) focus on the aspects of scientific thinking development in students. Scientific thinking has been shown to include skills related to research, experimentation, evidence evaluation, and deduction. In the provided empirical data, the object of scientific research is the thinking and reasoning skills related to the development of concepts and theories about the natural and social world. Moreover, Kang et al. (2016) believe that the process of the development of natural scientific thinking is influenced by various components of the tasks. We selected 57 science lessons taught by 19 teachers in the first year of study as empirical material. The obtained data show the importance of high-quality educational tasks, which carry an adequate level of epistemic uncertainty for a specific group of students. Scientists have proven that learning opportunities of higher quality have been observed in lessons where: 1) the tasks were formulated as a process of understanding contextualized phenomena; 2) specific disciplinary concepts in a task were associated with large scientific ideas going beyond the scope of the activity itself; 3) student were performing these tasks in a structured manner using tools that support changes in thinking.

In a study by Faikhamta (2013), the focus was shifted to examine the extent to which the Nature of Science Course (NOSC) developed in accordance with the Conceptualization of Pedagogical Content Knowledge (PCK) impacts understanding and teaching of science teachers on the job. The study results indicate that, at the beginning of the course, most natural science teachers had a naive understanding of NOS, especially with regard to the definition of science, scientific research, and differences between laws and theories. Shamina (2011) connects the need to diagnose natural scientific thinking of students with increased requirements for the quality of training of graduates of higher professional education institutions. The object of scientific understanding was the educational process in physics and biophysics at a veterinary university. The researcher identified three options for integrating the content of education in physics and biophysics: factual, conceptual, and theoretical.

Modeling, the works based on this approach are associated with the development and description of specific education models aimed at developing natural scientific thinking in the process of educational activities. The researches of Kubaisi (2011), Akanwa \& Ovute (2014), and Qarareh (2016) are focused on the study of development of systematic scientific thinking in the process of teaching natural sciences based on a constructionist education model. Scientists also propose a project method as a basis for developing natural scientific thinking. Students who took part in the "Summer Talent School" program improved their scientific thinking skills in the course of three-day workshops. The average score based on the test results is $74.2 \%$ of correct answers for the individual assessment of each question and $62.5 \%$ of correct answers for the coupled assessment method.

Of particular note is the theory of threshold concepts serving as the key to a deep understanding of specific disciplines (Kiley, 2019). Synergetic, an interdisciplinary approach explaining the development of natural scientific thinking as a process of integrating objects of the natural biological cycle (Dorfner et al., 2014; Kremer et al., 2014; Ivan and Šulcová, 2017; Özden \& Yenice, 2021). It has been shown that the use of combined knowledge in mathematics, chemistry, biology, geography, etc., increases the efficiency of the development of natural scientific thinking.

At the stage of the educational experiment, Ivan \& Šulcová (2017) used dedicated integrative educational materials as diagnostic tools. Interviews with high school mathematics, chemistry and science teachers were used to qualitatively diagnose knowledge (Ivan \& Šulcová, 2017). The studies of Kremer et al. (2014) are focused on the relation between students' research skills in biology and their beliefs in the nature of science. IRT modeling of students research skills showed that high school students demonstrate more advanced research skills in biology and more complex beliefs regarding NOS. Scientists have proven that the problems of development of natural scientific thinking are closely related to the study of the relationship between thinking and educational achievements. The works have the following in common: diagnosing the level of development of knowledge, skills and activities in the subjectoriented education system and focusing on the mechanisms of their creation.

The analysis of the scientific works showed that the development of natural scientific thinking in the process of educational activities is an urgent issue. The scientists focus on preschoolers, junior schoolchildren, students, and teachers. The issues related to the study of the aspects of the development of natural scientific thinking in foreign students of preparatory departments who come to Russia for education are beyond the field of view of scientists. By reviewing scientific-methodical and psychological-pedagogical literature, we can single out the existing contradictions bet- 
ween: 1) the need for evidence-based data on the quality of education of foreign students studying in Russian universities at the stage of pre-university training and the impossibility to assess the effectiveness of the educational process with accuracy; 2) the need for an objective assessment of the mental activity of foreign students studying in Russian universities at the stage of pre-university training and the lack of well-developed approaches that would allow us to diagnose the development of natural scientific thinking.

The starting point of pre-university training for foreign students is preparation of a broad-minded, well-rounded personality who has developed the competencies needed for their education, on-the-job training and professional activities, as well as competencies that allow them to establish intercultural contacts with representatives of other ethnic groups. The quality of development of educational and professional competence of doctors, biologists, agronomists, veterinarians is determined by the degree of development of their natural scientific thinking.

Up to now, natural science education has not been clearly defined. Here are the most common definitions: 1) a focused process and result of a person's developing a system of natural science knowledge, skills, cognitive and practical experience, values-based orientations and relationships (Vasilyeva, 2008; Gunstone, 2015; Lehrer \& Schauble, 2015); 2) designed to prepare specialists in natural sciences: biology, geology, geography, physics, astronomy, chemistry, mathematics, etc (Great Soviet Encyclopedia, 1972; Zimmerman \& Klahr, 2018). Thus, natural science education is a multi-level process developing a personality with a system of scientific knowledge in the field of biology, physics, chemistry, etc. Most existing definitions explain the specific features of natural science education through the content of natural science.

The content of the natural science cycle subjects and aspects of their teaching are defined in national standards. For example, a distinguishing feature of the National Science Education Standards (NSES) developed in the United States is that the natural science education process is oriented towards positive learners (students) and their activities; integrative nature of studying various subjects; stimulating interest in scientific activities and laboratory research; promotion of scientific thinking in the process of solving practical problems; teaching research methods; correlation with the needs and interests of the society; the use of technical advances in natural science education (McComas, 2013). It means that natural science teaching should focus on applying knowledge to new situations and developing intellectual abilities to face and solve everyday problems (Qarareh, 2016).

In Russia, national standards on natural science education have been developed for schools, colleges, and universities. No natural science education programs as such have been developed for the pre-university stage. This is due to the propaedeutic nature of courses in chemistry, biology and physics at the pre-university education stage. However, for many training areas, the natural science cycle subjects are the main ones. It should be noted that a significant drawback of the definitions of natural science education is that they fail to point out the personal aspect, according to which the result of natural science education is not only the total of the developed knowledge, skills and abilities, but also the personal properties of students, such as critical thinking, the ability to think outside the box, scientific view of life, and so forth. The basis for world perception of a modern human is predetermined by natural science education. The main achievements of material and spiritual culture are made due to the achievements of such natural science disciplines as chemistry, physics, biology, etc. (Alekseyev \& Cherednichenko, 2012).

As complex structured education, natural science education includes two levels of familiarization with the world: general and special. General science education includes systematic mastering of the foundations of natural sciences and general laws of nature. Generally, foreign students who come to Russia to study in a university already have general natural science training. Foreign students receive special natural science education in universities, regardless of their future specialty, in medical, agricultural, and pedagogical universities, as well as technical educational institutions.

In philosophy, thinking is understood as an active process of reflecting the objective world, which is related to solving a number of problems and the methods of mediated perception of reality (Philosophical Dictionary, 1991; Koerber et al., 2015). Holzkamp \& Sloan (2013) defines thinking from the standpoint of psychological processes. Thinking is a special reality that delivers indirect or direct knowledge of another, hidden reality unavailable for direct observation. The complexity and ambiguity of the concept of "thinking" led to the recognition of the fact that there are various types of thinking, and they all coexist in each person's consciousness. Preuniversity training of foreign students is aimed at preparation of future students with developed thinking. 
The degree of a person's mental development is the most important factor behind which underlays the level of training of students and the quality of acquisition of knowledge, skills, abilities and key competencies (Artemenko, 2011; Rastopchina, 2015). It should be noted that academic grades neither give an idea of specific knowledge of foreign students nor allow assessment of development processes. The development of the educational process subject is not linear, but stepwise. For convenience, we can divide it into two stages. The first stage is related to accumulation of quantitative changes. It is followed by the second stage, a leap, i.e., a sharp transition from quantitative changes to qualitative ones. The second stage begins after the quantitative changes reach the threshold value. Thus, the development of education subjects is a complex process of development of new qualitative and quantitative formations.

Starchenko \& Starchenko (2005) describe such basic new mental formations as educational and research activities, theoretical natural scientific thinking, and scientifically-oriented behavior. The initial concept is the statement of need for a differentiated approach to thinking. The subject content material is a means of developing thinking and a single process that acts as a linguistic, scientific, mathematical or technical process, if implemented based on the relevant subject material (Berulava, 1993). Improving the quality of education is associated with the level of acquisition of knowledge, development of skills and natural scientific thinking. It means that natural scientific thinking is viewed by researchers as the main new mental formation (Starchenko \& Starchenko, 2005).

The key didactics problem is the development of natural scientific thinking during the educational process. In our view, the key didactics problem is the development of natural scientific thinking during the educational process. When learning, students develop a scientific worldview and shape their vision of physical, chemical and biological processes. A factor of thinking development is the education content which determines the focus of the educational process. It means that the education content is the experience of cognitive activity, the ability to act according to a model, find unconventional solutions in difficult situations, a system of the person's norms and attitudes towards the world and self. At the stage of pre-university training, natural sciences are of practical importance for preparation of students enrolling in medical faculties and starting residency as they reveal the mechanisms of interaction between humans and the environment.
Physics and chemistry influence the quality of the development of natural scientific thinking. Physics is the building material, while biology is the architect and designer. While the inductive method of obtaining knowledge distinguishes biological education, physical education is characterized by the deductive method of obtaining knowledge which means learning the subject from simple to complicated. The content of biological and physical education is a symbiosis of theoretical and empirical knowledge accumulated by the educational process subjects because of their training. The continuity and interconnection of academic subjects at the stage of pre-university training ensures the systematization of knowledge at the factual level. Inter-subject relations between physics and biology are based on studying the influence of physical phenomena on living organisms. This means that the starting point is understanding of physical phenomena as biological processes.

Natural scientific thinking based on Surovikina (2005) is thinking that is formed and developed on the basis of the dialectical connection of structural components of physical, chemical and biological knowledge, characterized by transformation of objective reality into all kinds of models (figurative, sign, logical, etc.). Starchenko \& Starchenko (2005) understand natural scientific thinking as the process of reflecting the objective world in judgments, theories, concepts, and facts, where the cognitive process is based on the idea of unity of the material world, rising from the abstract to the concrete. It restores dialectical interconnections that eliminate contradictions between the mental representation and personal vision of the world. In a narrow sense, natural scientific thinking means integrative thinking developed in students as chemical, physical, biological thinking as a result of interconnection between subject-specific knowledge and methods of activity.

From the viewpoint of scientists, natural scientific thinking is a construct with the following characteristics: a) symbiosis of figurative, abstract, and logical components; b) quantitative and qualitative process of compiling knowledge from various subject areas; c) reliance on figurative modeling, mathematical transformation of the model and subsequent analysis in the process of logical construction; d) representation of reality confirmed empirically; e) mental activity as a process of transforming objective reality into figurative reality and changing it to a sign model; f) behavior of the mental activity process in the form of the following chain: sensory and visual perception of an object-transformation into a 
thought experiment-transformation of an object into integrity-logical generalization at a qualitatively new level.

Das (2014) discusses the need to identify the following elements of scientific thinking development: 1) Associative observation of natural elements and matter; 2) Thinking about natural growth processes; 3) Finding stages of natural phenomena and processes; 4) Critical thinking about the developed scientific theories; 5) Continuity, regularity, and direction of thinking: clockwise and counterclockwise;vertically up and down and from left to right; peripherally toward and away from the center; diagonal and transverse; linear and circular; from top to bottom and vice versa; 6) Searching for clarity against doubt; 7) Openness and prejudice; 8) Listening and interpreting statements; 9) Finding reasons for any event; 10) Finding consequences of conditions; 11) Logical operation of statements; 12) Divergent thinking, on the path of synthesis, a scientificthinking mind controls the waves of thought and often deviates in different directions; 13) Multifactorial convergent thinking; 14) Reflective thinking; 15) Inductive thinking; 16) Deductive thinking; 17) Science content concept; 18) Procedural actions as scientific methods.

Scientific thinking develops by influencing its components in the process of educational activity. Pedagogical solutions helping teachers understand and overcome students' learning challenges are useful (Kiley, 2019). The concept developed by Berulava (1993) is very close to our understanding of natural scientific thinking. Berulava discusses the need to identify four stages of development of natural scientific thinking.
The structure of natural scientific thinking developed by Berulava is shown in Figure 1. We believe that natural scientific thinking is a multilevel life-long mental formation. The low level of the development of natural scientific thinking is based on pre-scientific everyday ideas not related to attempts at scientific analysis of the task conditions. The everyday empirical stage is characterized by an empirical type of thinking. At this stage, students do not have scientific knowledge; they rely on pre-scientific ideas about the phenomena that occur in nature or living organisms in their logical judgments.

The average level of development of natural scientific thinking is characterized by the fact that subjects perform a scientific analysis of the task focusing on the specific conditions of interaction between material objects. However, they are not always able to apply knowledge to real conditions. This level corresponds to the scientific empirical stage of thinking development. Having reached the moderate level of thinking development, the student has a certain system of biophysical knowledge. However, students cannot apply this knowledge in their mental activity to solve tasks from other academic subjects. They cannot establish causal relationships between subjects.

The above-average level is characteristic of the differential synthetic stage, where educational activity subjects can identify causal relationships. They can identify intra-subject theoretical generalizations, finding it difficult to do so at the intersubject level. Students are well informed about the material, are able to analyze the patterns in the subject of study in question, but cannot do this at the inter-subject level.

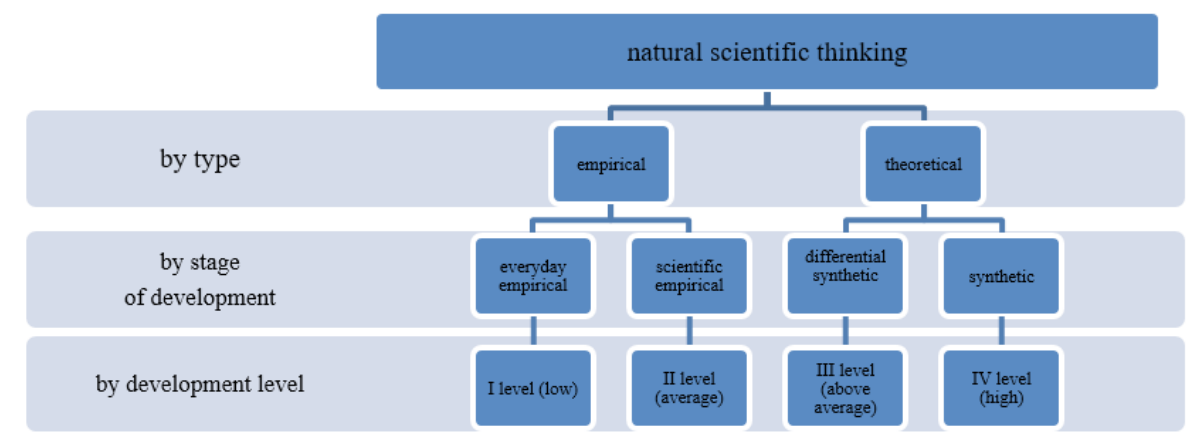

Figure 1. Natural Scientific Thinking Structure According to Berulava

The high level of thinking development is described as the synthetic stage. At this stage, students can navigate the interconnections and relationships between the material world objects. They have a high level of theoretical generalization and a high level of acquired knowledge. They can navigate the universal interconnections and relationships between material objects, as well as carry out inter-subject theoretical generalizations, and have a holistic view of the object of cognition. 
Thus, natural scientific thinking is a process of reflecting the world which is spasmodic in nature, associated with the accumulation of quantitative changes and qualitative changes reaching the threshold value. Natural scientific thinking is formed during educational and research activities and is integrative in nature. Berulava's structure of natural scientific thinking will be studied in further research using criteria-focused tests, which will help to expand its understanding.

Furthermore, the objectives of the research were: 1) to examine the stages of the development of natural scientific thinking in the context of the system of professional training of foreign students in Russian universities at the pre-university education stage; 2 ) to prove that we can overcome the crisis of modern education associated with the impoverishment of natural science ideas about the natural world by including an integrative online "biophysics" course in the curriculum; 3) synergy of the educational process, integration of physical and biological education contribute to the formation of a competency-based professional education model for future doctors, agronomists, veterinarians, and pharmacists.

\section{METHODS}

This theoretical and experimental research focuses on practical challenges of exploring the stages of development of natural scientific thinking of foreigners studying at Russian universities in an integrating educational environment of the Russian Federation through fundamental studies. The significance of the conducted research is determined by its practical focus. The control and experimental groups were trained under different curricula. The control group followed the conventional curriculum. The students studied chemistry, physics and biology according to the school curriculum of the Russian Federation. The experimental group studied an innovative integrative online course in biophysics.

The research included several stages. At the first stage (from January to June 2019), we analyzed the structure and content of the curricula, the regulations governing the educational process for foreign biomedical students at the stage of pre-university training, and psychological and pedagogical literature on the study topic. At this stage, the research was based on the principles of theoretical analysis (Jasso, 1988). Information analysis was carried out using the information content, information volume and information capacity criteria. An analysis of information sources was used as the main method. The informa- tion analysis of sources included the search for the original sources of information along with a preliminary review of their content. The methods of terminological analysis, and context analysis were also used.

At the second stage (from May to June 2019), diagnostic tests were selected to determine the degree of development of natural scientific thinking among foreign students of preparatory departments in the context of integration into the Russian educational environment, and the expert group was surveyed. The methodological basis for the study consisted of criterion-oriented tests. Criterion-based tests are used to evaluate the final level of learning; to select the students who have achieved the required level of training; to evaluate the training program effectiveness in a particular educational institution. These tests are very common. Thus, in a study by Lasch et al. (2020), criterion tests were used to study the quantitative characteristics of the behavior of children of early toddler age. Pechnikov \& Pechnikov (2015) use criterion-oriented testing of students to implement current pedagogical control based on the analysis of results. The proposed method for analyzing test results provides an evaluation of the effectiveness of training influences implemented in relation to the cognitive objects that appear in the corresponding test tasks, as well as an evaluation of the actual manifestation of the learning capacity.

The study of Shamina (2018) who uses criterion-oriented tests to diagnose the developed didactic model aimed at the development of natural scientific thinking is particularly important for our research. The content of diagnostics is revealed through a series of consecutive actions: indicative and constructive, organizational and corrective, evaluative and effective, as well as analytical and prognostic. An experimental study by Shamina was based on studying the processes of natural scientific thinking development in schoolchildren. High school graduates, i.e., people who essentially should have already developed a high level of natural scientific thinking is beyond the researcher's field of view. Also beyond the scientists' field of view are foreign students studying at the preparatory departments.

A criterion-oriented test was used as a diagnostic tool to assess the development of natural scientific thinking. One of the first attempts to use criterion-oriented tests to assess the degree of development of natural scientific thinking among pedagogical college students was made by Alekseev \& Cherednichenko (2012). Criterionoriented tests are represented by tasks aimed at 
assessing the achievements according to specific stages on the basis of which the process is organized. Grigoryeva (2015) identified the following assessment criteria: "space", "time", "field", "substance", "energy". This study methods were based on Shamina's article "Diagnosing Natural Scientific Thinking of Students in the Context of Integration of Physical and Biological Education Content (the Case of a Veterinary University)" (2011).

The TEM-11 test (developed by Starchenko \& Starchenko, 2005) was used as the diagnostic tool; it was originally developed to assess the level of development of thinking of $11^{\text {th }}$ grade students of a natural science school who have already mastered the system of scientific knowledge in biology, chemistry and physics. The criteria-focused test involved the monitoring of education throughout the training period based on three criteria. The first criterion, knowledge quality monitoring, is based on the assessment of achievement level among foreign students of faculties of pre-university training. The assessment of knowledge they gained was treated as a qualitative indicator of natural scientific thinking. The second criterion is called the influence of natural scientific education on the stage of development of natural scientific thinking. Foreign students' natural scientific knowledge is assessed to keep up with science developments, the ability to integrate and systematize physical, biological, chemical and humanities knowledge. The third criterion, natural scientific focus of students, is related to students' attitude to natural scientific cognitive activity, recognition of its necessity, ability to use natural scientific knowledge in learning cognitive and professional activities. Criterion-oriented tests are distinguished by the criterion-based approach to diagnosing the achievements of the student's personality, as well as recognition of the fact that results are achieved on an individual basis and the success of an individual student does not depend on achievements of the others.

The main requirements for tests are reliability and validity. Internal and external validity are distinguished. Internal validity means that the research results are justified depending on the criteria for selecting a group, recording experiment data. External validity is associated with the transfer of the obtained results to other reference groups (Lasch et al., 2020). To meet these requirements, we used the method of expert assessments. There were 2 expert groups. The first group consisted of subject teachers and se- nior students. They were offered a questionnaire that required a detailed answer (judgment). The second group consisted of subject teachers who excluded non-scientific (trivial) statements from the forms for possible judgments. The qualitative approach was used as a scientific toolkit (Faikhamta, 2013).

The degree of difficulty of tasks is calculated by the formula:

$$
P=\frac{N s}{N}
$$

$P \quad$ : degree of difficulty of the task,

Ns : number of students who chose the correct judgment,

$N \quad$ : total number of students who completed the test.

The task difficulty value ranges from 0.3 to 0.7 (Berulava, 1993).

At the third stage (from September to November 2019), we conducted an ascertaining experiment. Two groups of respondents participated in the ascertaining experiment: the control group, 186 students $(\mathrm{n}=186)$ of the preparatory faculty, including residents $(\mathrm{n}=17)$, first-year students enrolling in medical $(n=148)$ and agrarian faculties $(n=21)$, experimental group, 188 students $(n=188)$ of the preparatory faculty, including residents $(n=21)$, first-year students enrolling in medical $(n=140)$ and agrarian faculties $(n=27)$. The training groups had approximately the same composition. The homogeneity of the control and experimental groups determined the accuracy of the experiment.

The results were processed using the following formula:

If $\mathrm{Ne}>\mathrm{Nn}$, natural scientific thinking is at the empirical stage,

If $\mathrm{Ne}>0$, natural scientific thinking is at the everyday empirical stage,

If $N e=0,0.83>\mathrm{K} .0 .65$, natural scientific thinking is at the differential synthetic stage,

If $N e=0, K s \geq 0.83$, natural scientific thinking is at the synthetic stage, where

$\mathrm{Ne} \quad$ : number of everyday judgments,

$\mathrm{Nn} \quad$ : number of subject-specific judgments,

Ks : rate of solving tasks based on the synthesized solution,

The results of the ascertaining experiment for development of natural scientific thinking among students of a preparatory department are shown in Table 1. 
Table 1. Stages of Natural Scientific Thinking Development in Control and Experimental Sample Groups at the Ascertaining Experiment Stage

\begin{tabular}{lcccccccc}
\hline \multirow{2}{*}{$\begin{array}{l}\text { Sample } \\
\text { Group }\end{array}$} & \multicolumn{7}{c}{ Natural Scientific Thinking Development Stages } \\
\cline { 2 - 9 } & Everyday Empirical & \multicolumn{2}{c}{ Scientific Empirical } & Differential Synthetic & \multicolumn{2}{c}{ Synthetic } \\
\cline { 2 - 9 } & $\mathbf{n}$ & $\%$ & $\mathbf{n}$ & $\%$ & $\mathbf{n}$ & $\%$ & n & $\%$ \\
\hline $\begin{array}{l}\text { Experimental } \\
\text { group }\end{array}$ & 53 & $28.2 \%$ & 75 & $39.9 \%$ & 44 & $23.4 \%$ & 16 & $8.5 \%$ \\
\begin{tabular}{l} 
Control group \\
\hline
\end{tabular} & 58 & $31.2 \%$ & 75 & $40.3 \%$ & 39 & $21 \%$ & 14 & $7.5 \%$ \\
\hline
\end{tabular}

The ascertaining experiment materials show that natural scientific thinking of preparatory department students mainly corresponds to the empirical stage. Thus, out of 186 respondents in the control group, the everyday empirical stage of natural scientific thinking is observed in $31.2 \%$ of the respondents, scientific empirical in $40.3 \%$, differential synthetic in $21 \%$, synthetic in $7.5 \%$. Among 188 respondents in the experimental group, $28.2 \%$ of the respondents are at the everyday empirical stage and $39.9 \%$ are at the scientific empirical stage. Only $8.5 \%$ of the respondents have developed the synthetic stage of natural scientific thinking. The differential synthetic stage is observed in $23.4 \%$ of respondents.

The experiment results show that natural scientific thinking among students who have begun to study Biophysics are characterized by a low level of development of the theoretical type. Although the traditional program of corrective courses in Physics and Biology taught to foreigners at the preparatory department starting from the 5th week of study implies that the students have already mastered the system of scientific knowledge, and their thinking is at or approaching the differential synthetic stage.

At the third stage (from October 2019 to May 2020), we conducted an educational experiment. At this stage, we analyzed the impact of the contents of an integrative online course in biophysical education on development of natural scientific thinking of foreign students at the stage of pre-university training. The students who took part in the experiment were relatively homogeneous. The initial hypothesis of the experiment was that the innovative biophysics online course contributes to the development of natural scientific thinking in foreign students of pre-university courses in the context of integration into the Russian educational environment. A distinctive feature of this course is the study of physical phenomena and processes, as well as physical and chemical mechanisms underlying biological processes that occur at various levels of organization of living matter.
The educational experiment involved training the experimental group on the innovative course in biophysics required for medical students, pharmacists, veterinarians, agronomists, etc. Foreign students study biophysics via online classes, as well as distance lectures and practical materials. Unlike the physics and biology courses taught at preparatory departments, the innovative course is propaedeutic, integrating with physics, biology courses and subsequent academic disciplines.

The online course in biophysics consists of an invariable and a variable part. Let us consider the main modules of practical training of foreign students of the preparatory departments. Membrane biophysics: elementary living system, barrier, matrix, mechanical, energetic, receptor and generative functions of biological membranes, biological membranes, electrical parameters of biological membranes, freeze-fracture-etching method, fluid mosaic model of biological membrane structure, phospholipid molecules in membranes, membrane mobility and dynamics, fluorescence analysis, electron paramagnetic resonance, nuclear magnetic resonance, flip-flop, lipid phase transitions in membranes, lipid bilayer membranes, single-layer liposome structure, planar bilayer lipid membrane, passive transport of substances across the membrane, active transport of substances, Ussing's experiment, membrane stability and permeability, membrane potential, and resting potential.

Cell and organ biophysics: single equivalent generator model, fundamental physical principles of electrocardiography, vector electrocardiography, electroencephalography, autowave processes, autowaves in organs and tissues, free oscillation, forced oscillation and self-oscillation, active medium, autowaves in homogeneous media, excitation, "refractory" tail and rest as the basic states of cells in an active medium, properties of reverberators, muscle activity, muscle cell, sliding filament model, muscle biomechanics, Hill's equation, single contraction power, muscle contraction modeling, and electromechanical 
coupling. Biophysical processes: modeling of biophysical processes, modeling stages, physical model, biological model, mathematical model, natural population growth model (Malthusian model), population dynamics model with intraspecific competition (Verhulst model), predatorprey model (Volterra model), pharmacokinetic model, biophysics of the circulatory system, fluid viscosity (internal friction), non-Newtonian fluid, hemodynamics, pressure, linear velocity, hydraulic resistance, linear velocity of blood flow, mean pressure distribution, biophysical functions of cardiovascular system elements, kinetics of blood flow in elastic vessels, pulse wave, Funk model, blood flow dynamics in capillaries, filtration and reabsorption processes, specific aspects of blood flow during local vasoconstriction, resistive model, biological cybernetics, principle of automatic regulation in living systems, and information flows in living systems.

Biosphere and physical fields: matter and field as components of a single material world, natural sources of electromagnetic radiation, interaction between electromagnetic radiation and matter, types and properties of radioactive radiation, ionizing radiation, the natural background radiation of the Earth, and electromagnetic and radioactive radiation in medicine. Physical fields of the human body: sources of physical fields, electromagnetic fields, acoustic fields, infrared radiation, mechanisms of temperature change in the human body, optical radiation of the human body, and acoustic fields of a human.

At the fourth stage (the second semester of the 2019/2020 academic year), we conducted an ascertaining experiment (Table 2).

Table 2. Stages of Natural Scientific Thinking Development in Control and Experimental Sample Groups at the Ascertaining Experiment Stage

\begin{tabular}{lcccccccc}
\hline & \multicolumn{7}{c}{ Natural Scientific Thinking Development Stages } \\
\cline { 2 - 8 } Sample Group & Everyday Empirical & Scientific Empirical & Differential Synthetic & \multicolumn{2}{c}{ Synthetic } \\
\cline { 2 - 8 } & $\mathbf{n}$ & $\mathbf{\%}$ & $\mathbf{n}$ & $\mathbf{\%}$ & $\mathbf{n}$ & $\mathbf{\%}$ & $\mathbf{n}$ & $\%$ \\
\hline $\begin{array}{l}\text { Experimental } \\
\text { group (n=188) }\end{array}$ & 21 & $11.2 \%$ & 31 & $16.5 \%$ & 84 & $44.7 \%$ & 52 & $27.6 \%$ \\
$\begin{array}{l}\text { Control group } \\
(\mathrm{n}=186)\end{array}$ & 56 & $30.1 \%$ & 61 & $32.8 \%$ & 50 & $26.9 \%$ & 19 & $10.2 \%$ \\
\hline
\end{tabular}

After studying each module, a control section was made. Each module ("membrane biophysics", "cell and organ biophysics", "biophysical processes", "biosphere and physical fields", "physical fields of the human body") requires acquisition of a certain set of knowledge. We assess the development of natural scientific thinking based on the problem-solving skills foreign students have. The compiled problems do not require complex calculations, since they make foreign students appeal to the knowledge they acquired during the education process. The tasks are based on inter-subject generalizations, some kind of synthesis of physical, biological and other knowledge and are of formalized nature, since they include a set of formalized judgments from which students need to choose the correct answer.

\section{RESULTS AND DISCUSSION}

Foreigners enrolled at faculties of pre-university training of Russian biological universities differ in their level of natural scientific thinking. However, it is natural-scientific thinking that pre- determines the foreigners' achievements in disciplines, attitude to natural scientific cognitive activities, etc. Traditional training programs for foreign students at the pre-university stage clearly contribute to increasing the level of development of natural scientific thinking. However, the analysis of syllabi and curricula of faculties of pre-university training showed that the existing system of training of foreigners at faculties of pre-university training is focused on improving knowledge of chemistry, physics, and biology. Its obvious disadvantage is the lack of interdisciplinary knowledge integration. Knowledge gained is often superficial. Students barely have generalized universal knowledge about the essence of the world around them. That is, despite knowledge generation, natural scientific thinking is still at the common empirical and scientific empirical stages (Fig. 2). The formative experiment findings show that including the academic subject "biophysics" in the educational process at the pre-university training stage accelerates the pace of natural development of scientific thinking. 


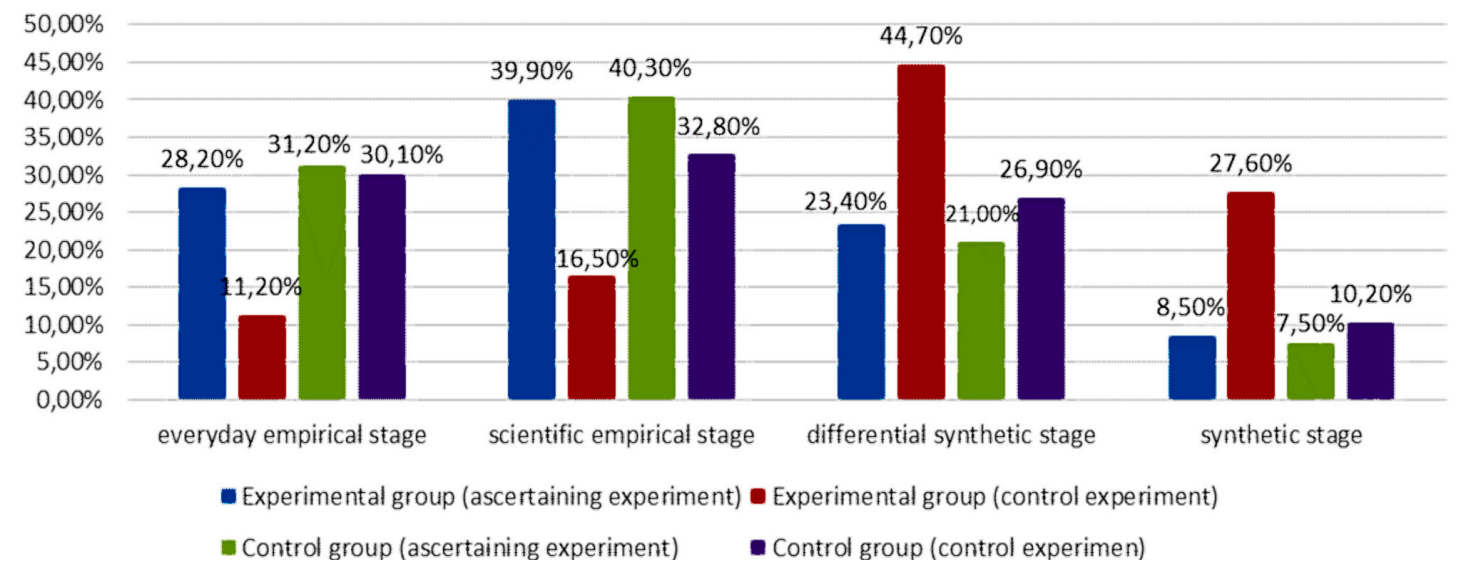

Figure 2. Results of Natural Scientific Thinking Development Assessment in Respondents Depending on Their Training Profile at the Ascertaining and Control Experiment Stages

The control experiment results demonstrate progress in the experimental group. It should be noted that, when foreign students begin to study an academic subject, have subject-specific knowledge, but they are not systematized. As they study the online course in biophysics, the number of foreign students with the scientific empirical stage of natural scientific thinking increases. The number of respondents at the everyday empirical $(11.2 \%)$ and scientific empirical (32.8\%) stages has decreased significantly. The number of respondents with the differential synthetic (44.7\%) and synthetic $(27.6 \%)$ stages of natural scientific thinking development increased. Progress in the control group was insignificant: $30.1 \%$ of the respondents had the everyday empirical stage, $32.8 \%$ had the scientific empirical stage, $19 \%$ had the differential synthetic stage, $10.2 \%$ had the synthetic stage.

The degree of natural scientific thinking development was further evaluated on the basis of the identified profile groups (Figure 3). The most important condition for development of natural scientific thinking is an integrated course in biophysics containing a high cognitive and content potential. However, the extent to which the biophysics course affects students depends on the level of their initial training.

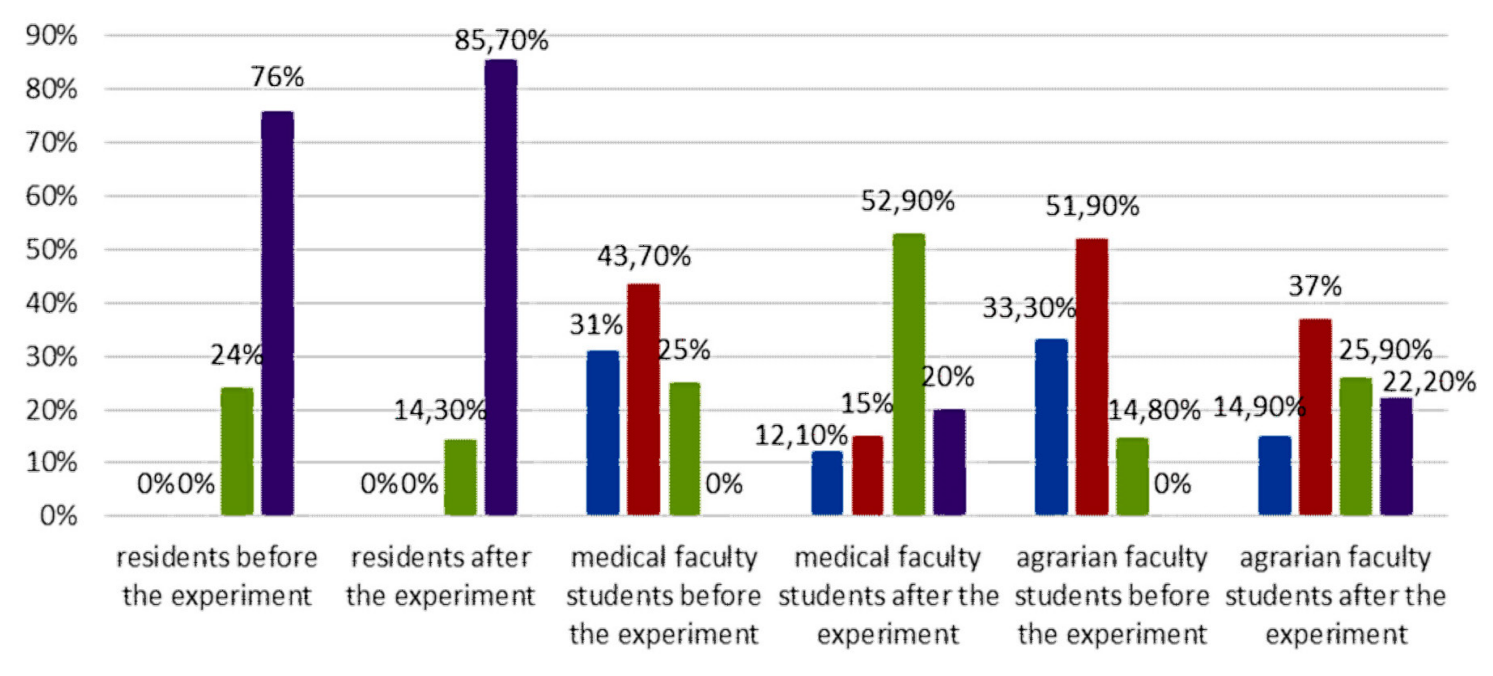

- everyday empirical stage scientific empirical stage differential synthetic stage anthetic stage

Figure 3. Results of Natural Scientific Thinking Development Assessment in Respondent Groups at the Ascertaining and Control Experiment Stages 
A comparative analysis of the ascertaining and control experiment results showed that residents, as they have already passed professional training, have a higher level of development of natural scientific thinking. All residents have natural scientific thinking at the stage of synthetic thinking, meaning that they have theoretical generalization and synthesis skills. Having completed the course in biophysics, foreign students enrolling to the first year of a medical faculty demonstrate noticeable progress in the level of natural scientific thinking development. The number of foreign students who have the empirical stage of the natural scientific thinking development decreased. The number of students with the differential synthetic $(52.9 \%)$ and synthetic $(22.2 \%)$ stages increased.

Moreover, progress is observed in the group of foreign students enrolling in an agrarian faculty. Before the experiment, the empirical stage of natural scientific thinking development prevailed among the students, whereas the differential synthetic and synthetic stages prevailed after. Further analysis was conducted for the "membrane biophysics", "cell and organ biophysics", "biophysical processes", "biosphere and physical fields", "physical fields of the human body" modules. Here we established that the quality of development of natural scientific thinking depends on the extent of intra-subject synthesis implemented during the educational process via scientifically developed modules and courses. The modular integrative course in biophysics at the pre-university training stage contributes to the development of theoretical thinking in foreigners.

A certain percentage of the planned volume of retention of the required material was used as the assessment criteria. After completing each module, foreign students wrote a control test on the basis of which we evaluated the degree of development of natural scientific thinking. A comparative analysis of these results of the TEM-11 ascertaining experiment in the control and experimental groups of residents shows that residents of both groups have a high level of development of natural scientific thinking (Table 3). This is explained by the fact that the knowledge they acquired previously contributes to the professional growth of residents and facilitates the process of forming professional competence.

As for students receiving language and subject training at preparatory departments of Russian universities for admission to residency, we initially assumed that they should already have a high level of natural scientific thinking. The experimental data confirmed our assumptions. Initially, residents have levels 3 and 4 of natural scientific thinking development.

Table 3. Comparative Analysis of the TEM-11 Control and Ascertaining Experiment Results in the Experimental Group of Residents

\begin{tabular}{|c|c|c|c|c|c|c|c|c|}
\hline \multirow[b]{3}{*}{ Test (Modules) } & \multicolumn{8}{|c|}{ Natural Scientific Thinking Development Stages } \\
\hline & \multicolumn{2}{|c|}{ Everyday Empirical } & \multicolumn{2}{|c|}{ Scientific Empirical } & \multicolumn{2}{|c|}{ Differential Synthetic } & \multicolumn{2}{|c|}{ Synthetic } \\
\hline & 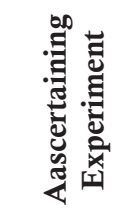 & 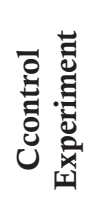 & 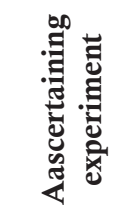 & 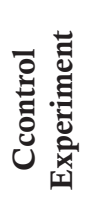 & 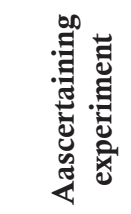 & 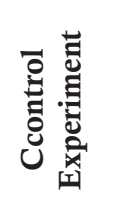 & 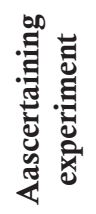 & 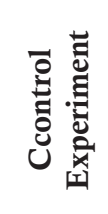 \\
\hline $\begin{array}{l}\text { Membrane } \\
\text { biophysics }\end{array}$ & - & - & - & - & $7 \%$ & $3 \%$ & $21 \%$ & $19 \%$ \\
\hline $\begin{array}{l}\text { Cell and organ } \\
\text { biophysics }\end{array}$ & - & - & - & - & $3 \%$ & $3.3 \%$ & $15 \%$ & $17.5 \%$ \\
\hline $\begin{array}{l}\text { Biophysical } \\
\text { processes }\end{array}$ & - & - & - & - & $4 \%$ & $3 \%$ & $12 \%$ & $11.7 \%$ \\
\hline $\begin{array}{l}\text { Biosphere and } \\
\text { physical fields }\end{array}$ & - & - & - & - & $8 \%$ & $3 \%$ & $18 \%$ & $18 \%$ \\
\hline $\begin{array}{l}\text { Physical fields } \\
\text { of the human } \\
\text { body }\end{array}$ & - & - & - & - & $2 \%$ & $2 \%$ & $10 \%$ & $19.5 \%$ \\
\hline
\end{tabular}

The level of natural scientific thinking development among residents is at a fairly high level and corresponds to levels 3 and 4 of scientific thinking development. Studying the integrative course in biophysics has not changed the indi- cators significantly. This allows us to conclude that it is not reasonable to include the biophysics integrative course in the curriculum of residents studying at the preparatory courses. 
In the case of foreign students studying at the preparatory departments of Russian universities in order to enroll in the main courses of medical (Table 4) or agricultural faculties (Table 5), we are talking about people with secondary education or non-major higher education. Their low level of development of natural scientific thinking is associated with a low level of formation of the cognitive potential of the students. They have poorly developed skills of systematizing the knowledge they gained while studying physics, chemistry and biology at the previous school stage of education, which are the basis for the natural scientific thinking development.

Table 4. Comparative Analysis of the TEM-11 Control and Ascertaining Experiment Results in the Experimental Group of Medical Faculty Students

\begin{tabular}{|c|c|c|c|c|c|c|c|c|}
\hline \multirow[b]{3}{*}{ Test (Modules) } & \multicolumn{8}{|c|}{ Natural Scientific Thinking Development Stages } \\
\hline & \multicolumn{2}{|c|}{ Everyday Empirical } & \multicolumn{2}{|c|}{ Scientific Empirical } & \multicolumn{2}{|c|}{ Differential Synthetic } & \multicolumn{2}{|c|}{ Synthetic } \\
\hline & 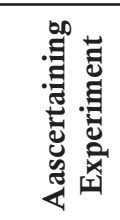 & 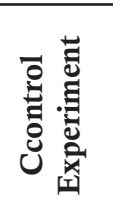 & 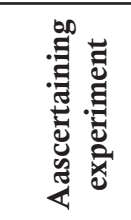 & 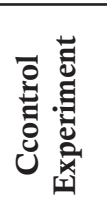 & 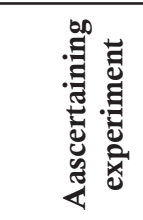 & 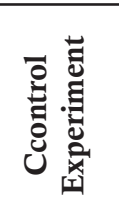 & 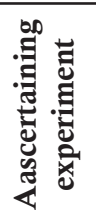 & 흘 \\
\hline $\begin{array}{l}\text { Membrane bio- } \\
\text { physics }\end{array}$ & $6 \%$ & $3.3 \%$ & $7 \%$ & $3 \%$ & $7 \%$ & $10.6 \%$ & - & $6.7 \%$ \\
\hline $\begin{array}{l}\text { Cell and organ } \\
\text { biophysics }\end{array}$ & $4 \%$ & $0.7 \%$ & $6 \%$ & $2.1 \%$ & $4 \%$ & $11.3 \%$ & - & $3.3 \%$ \\
\hline $\begin{array}{l}\text { Biophysical pro- } \\
\text { cesses }\end{array}$ & $10 \%$ & $3.3 \%$ & $7 \%$ & $2.6 \%$ & $3 \%$ & $12.5 \%$ & - & $0.7 \%$ \\
\hline $\begin{array}{l}\text { Biosphere and } \\
\text { physical fields }\end{array}$ & $6 \%$ & $2.7 \%$ & $12 \%$ & $4 \%$ & $5 \%$ & $12.5 \%$ & - & $5.1 \%$ \\
\hline $\begin{array}{l}\text { Physical fields of } \\
\text { the human body }\end{array}$ & $5.3 \%$ & $2.1 \%$ & $11.7 \%$ & $3.3 \%$ & $6 \%$ & $6 \%$ & - & $4.2 \%$ \\
\hline
\end{tabular}

The results of the ascertaining and control experiments show that the integrative course in biophysics contributes to development of differential synthetic and synthetic levels of thinking. While foreign students studying at a preparatory department of the medical profile initially failed to demonstrate a synthetic level of natural scientific thinking development, after completing all the modules of the biophysics course, the synthetic level was observed. The highest percentage of $6.7 \%$ was obtained for the "membrane biophysics" module. It is followed by the "biosphere and physical fields" module at $5.1 \%$, "physical fields of the human body" at $4.2 \%$, "cell and organ biophysics" at 3.3\%, "biophysical processes" at $0.7 \%$. Similar data were recorded in the group of foreign students of an agrarian profile (Table 5).

Table 5. Comparative Analysis of the TEM-11 Control and Ascertaining Experiment Results in the Experimental Group of Agrarian Faculty Students

\begin{tabular}{|c|c|c|c|c|c|c|c|c|}
\hline \multirow[b]{3}{*}{ Test (Modules) } & \multicolumn{8}{|c|}{ Natural Scientific Thinking Development Stages } \\
\hline & \multicolumn{2}{|c|}{ Everyday Empirical } & \multicolumn{2}{|c|}{ Scientific Empirical } & \multicolumn{2}{|c|}{ Differential Synthetic } & \multicolumn{2}{|c|}{ Synthetic } \\
\hline & 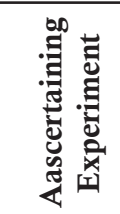 & 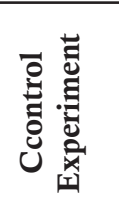 & 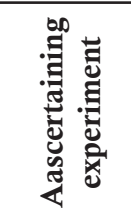 & 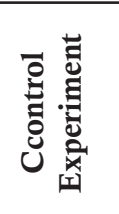 & 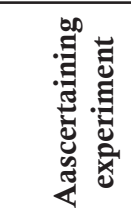 & 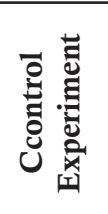 & 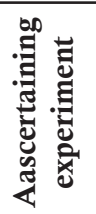 & 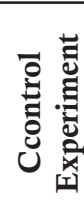 \\
\hline $\begin{array}{l}\text { Membrane bio- } \\
\text { physics }\end{array}$ & $8 \%$ & $4.9 \%$ & $16 \%$ & $8.6 \%$ & $2 \%$ & $6.5 \%$ & - & $8.7 \%$ \\
\hline $\begin{array}{l}\text { Cell and organ } \\
\text { biophysics }\end{array}$ & $7 \%$ & $3.3 \%$ & $8 \%$ & $6 \%$ & $4 \%$ & $5.3 \%$ & - & $4.2 \%$ \\
\hline $\begin{array}{l}\text { Biophysical pro- } \\
\text { cesses }\end{array}$ & $6 \%$ & $3.3 \%$ & $8 \%$ & $8.5 \%$ & $2 \%$ & $6.9 \%$ & - & $5.3 \%$ \\
\hline $\begin{array}{l}\text { Biosphere and } \\
\text { physical fields }\end{array}$ & $6.3 \%$ & $2.1 \%$ & $7 \%$ & $6.4 \%$ & $3.8 \%$ & $4.2 \%$ & - & $0.7 \%$ \\
\hline $\begin{array}{l}\text { Physical fields of } \\
\text { the human body }\end{array}$ & $6 \%$ & $1.3 \%$ & $12.9 \%$ & $7.5 \%$ & $3 \%$ & $3 \%$ & - & $3.3 \%$ \\
\hline
\end{tabular}


The data obtained show that future agrarians also demonstrated major changes while studying the integrative course. The IV (synthetic) level of scientific thinking has developed. The highest percentage of $8.7 \%$ was obtained for the "membrane biophysics" module. It is followed by the "biophysical processes" module at $5.3 \%$, "cell and organ biophysics" at $4.2 \%$, "physical fields of the human body" at 3.3\%, "biosphere and physical fields" at $0.7 \%$. To sum up the abo$\mathrm{ve}$, the conducted comparative analysis showed that foreign students enrolling in medical and agricultural faculties show qualitative and quantitative changes in the stages of natural scientific thinking development while studying the online course in biophysics. Before starting the biophysics course, the overwhelming majority of foreign students enrolling in medical and agrarian faculties have formed an everyday empirical, scientific empirical stage. This indicates that foreign students have certain subject knowledge, are in the process of accumulating it, but they do not have inter-subject generalization skills. The differential synthetic stage of natural scientific thinking in foreign students enrolling in medical and agrarian faculties has developed partially, while the synthetic stage has not developed. While studying the "membrane biophysics", "cell and organ biophysics", "biophysical processes", "biosphere and physical fields", "physical fields of the human body" modules, foreign students undergo significant changes in the levels of development of their natural scientific thinking.

Qualitative changes associated with development of the synthetic stage of natural scientific thinking confirm the hypothesis that the inclusion of the biophysics integration course in the curricula of the preparatory department forms the skills of establishing inter-subject connections in foreign students. Thus, studying the biophysics course reveals specific aspects of interaction between the individual and the environment, which provides the basis for development of professional thinking in the future. Accordingly, we can speak of the applied nature of natural scientific thinking ensuring the integration of Russian education into the common European environment.

\section{CONCLUSION}

The experiment findings show that the cycle of natural scientific disciplines has a great influence on the natural scientific thinking of foreigners studying at faculties of pre-university training of Russian universities. Physics, chemistry and biology are integral components of biomedical training of foreigners. However, in spite of the labor- and energy-intensive nature of these courses, the post-raining level of development of natural thinking in most foreigners remains rather low and corresponds to the empirical type of thinking. The formative experiment in the experimental group as well as the ascertaining experiments in the control and experimental groups show that the Biophysics integrative online course contributes to improving the quality of natural scientific education and, consequently, switching natural scientific thinking to the theoretical type. When studying the Biophysics integrative online course, foreign students generate universal knowledge and scientific forms of thinking, which provide the best possible conditions for the integration of foreign students into the new educational environment. The experimental data suggest that the experimental groups of future medical and agricultural students studying under the innovative curriculum have strong dynamics of natural scientific thinking evolving to the synthetic differential stage. The dynamics of natural scientific thinking evolving to the synthetic stage as the top level of development of natural scientific thinking, which will be further enhanced in basic courses of universities, is also evident. Foreign medical residents show slow improvements in forming the synthetic type of thinking. They have already completed their specialist programs and have the necessary level of natural scientific thinking.

\section{ACKNOWLEDGEMENTS}

This paper is financially supported by the RUDN University Strategic Academic Leadership Program.

\section{REFERENCES}

Akanwa, U. N., \& Ovute, A. O. (2014). The effect of constructivist teaching model on SSS Physics students' achievement and interest. Journal of Research and Method in Education, 4(1), 35-38.

Alekseev, V.I., \& Cherednichenko, A.I. (2012) Intellectual development and training on the basis of information educational technologies. Russian Journal of Education and Psychology, (12).

Artemenko, O.N. (2011) Scientific Approaches to Determining the Interdependence of Mental Development and Achievements in Learning Activities of Younger School Children. Stavropol State University Herald, 2, 133-138.

Berulava G.A. (1993). Thinking Diagnostics and Development in Adolescents. Biysk. Scientific Publishing Center of the Biysk Pedagogical Institute, 240.

Broks, A. (2014). Scientific thinking: The backbone of modern science and technology educa- 
tion. Journal of Baltic Science Education, 13(6), 764.

Das, M. K. (2014). Elements for development of scientific thinking. Journal of Research \& Method in Education. 4(5), 28-32.

Dorfner, T., Förtsch, C., Germ, M., \& Neuhaus, B. J. (2018). Biology instruction using a generic framework of scientific reasoning and argumentation. Teaching and Teacher Education, 75, 232-243.

Faikhamta, C. (2013). The development of in-service science teachers' understandings of and orientations to teaching the nature of science within a PCK-based NOS course. Research in Science Education, 43(2), 847-869.

Great Soviet Encyclopedia (1972). In 30 volumes. Chief editor Prokhorov, A.M. Moscow: Sovetskaya Entsyklopediya, V. 9, 664.

Grigoryeva, Ye.V. (2015) Methodology of Teaching Natural Science in Elementary School: Textbook for Students of Pedagogical Universities. Grigoryeva, Ye.V. $-2^{\text {nd }}$ edition, revised and updated - Chelyabinsk: Publishing House of Chelyabinsk State Pedagogical University, 283.

Gunstone, R. (2015). Encyclopedia of science education. Springer Reference.

Holzkamp, K., \& Sloan, T. (2013). Psychology from the standpoint of the subject: Selected writings of Klaus Holzkamp. Palgrave Macmillan.

Ivan, M., \& Šulcová, R. (2017). Mathematics, chemistry and science connection as a basis of scientific thinking. In SHS Web of Conferences (Vol. 37, p. 01017). EDP Sciences.

Jasso, G. (1988). Principles of theoretical analysis. Sociological Theory, 1-20.

Kang, H., Windschitl, M., Stroupe, D., \& Thompson, J. (2016). Designing, launching, and implementing high quality learning opportunities for students that advance scientific thinking. Journal of Research in Science Teaching, 53(9), 13161340.

Kiley, M. (2019). Threshold concepts of research in teaching scientific thinking. In Redefining scientific thinking for higher education (pp. 139155). Palgrave Macmillan, Cham.

Klahr, D., Zimmerman, C., \& Matlen, B.J. (2019). Improving students' scientific thinking. The Cambridge handbook of cognition and education. Cambridge University, 67-99.

Koerber, S., Mayer, D., Osterhaus, C., Schwippert, K., \& Sodian, B. (2015). The development of scientific thinking in elementary school: A comprehensive inventory. Child Development, 86(1), 327-336.

Koerber, S., \& Osterhaus, C. (2019). Individual differences in early scientific thinking: assessment, cognitive influences, and their relevance for science learning. Journal of Cognition and Development, 20(4), 510-533.
Kremer, K., Specht, C., Urhahne, D., \& Mayer, J. (2014). The relationship in biology between the nature of science and scientific inquiry. Journal of Biological Education, 48(1), 1-8.

Kubaisi, A. (2011). The effect of using constructivist learning model on the achievement of intermediate stage in mathematics and systematic thinking. Basrah Journal for humanities, 32(1), 106-126.

Lasch, C., Wolff, J. J., \& Elison, J. T. (2020). Examining criterion-oriented validity of the repetitive behavior scales for early childhood (RBS-EC) and the video-referenced rating of reciprocal social behavior (vrRSB). Development and psychopathology, 32(3), 779-789.

Lehrer, R., \& Schauble, L. (2015). The Development of Scientific Thinking. Handbook of Child Psychology and Developmental Science, 1-44.

McComas, W. F. (Ed.). (2013). The language of science education: an expanded glossary of key terms and concepts in science teaching and learning. Springer Science \& Business Media.

Murtonen, M., \& Salmento, H. (2019). Broadening the theory of scientific thinking for higher education. In Redefining Scientific Thinking for Higher Education (pp. 3-29). Palgrave Macmillan, Cham.

Özden B., \& Yenice N. (2021) The Relationship between Scientific Inquiry and Communication Skills with Beliefs about the Nature of Science of Pre-Service Science Teachers'. Participatory Educational Research, 9(1), 192-213.

Pechnikov, A. N., \& Pechnikov, D. A. (2015). Solving Problems of Current Pedagogical Control by Analyzing Criterion-Oriented Testing Results. Educational Technologies and Society, 18(2), 489513.

Philosophical Dictionary (1991). Ado, A.V., et al]; under the editorship Frolov, I.T. $-6^{\text {th }}$ edition, revised and updated, 559.

Purnami, W., Sarwanto, S., Suranto, S., Suyanti, R., \& Mocerino, M. (2021). Investigation of Science Technology Ecocultural Society (STEcS) Model to Enhance Eco Critical Thinking Skills. Journal of Innovation in Educational and Cultural Research, 2(2), 77-85.

Qarareh, A. O. (2016). The Effect of Using the Constructivist Learning Model in Teaching Science on the Achievement and Scientific Thinking of 8th Grade Students. International Education Studies, 9(7), 178-196.

Rastopchina, O.M. (2015) Criteria of Diagnostics of Levels of Knowledge and Competences of Students. Eurasian Union of Scientists, 5(14), 105109.

Shamina S.V. (2011). Diagnosing Natural Scientific Thinking of Students in the Context of Integration of Physical and Biological Education Content (the Case of a Veterinary University). [ $\mathrm{PhD}$ in Pedagogy Thesis]. Chelyabinsk, 212. 
Shamina, S.V. (2018). Didactic Modeling of Diagnostics of Natural Scientific Thinking of University Students. Current Challenges of Science and Education, 1, 36.

Starchenko, S.A., \& Starchenko, V.A. (2005). Development of Natural Scientific Thinking among Lyceum Students. Chelyabinsk. Chelyabinsk State Pedagogical University, 61.

Surovikina, S.A. (2005). Development of Students' Natural Scientific Thinking in the Process of Teaching Physics.

Taber, K. S. (2012). The Natures of Scientific Thinking: Creativity as the Handmaiden to Logic in the Development of Public and Personal
Knowledge. Advances in Nature of Science Research Concepts and Methodologies, 51-74

Taber, K. S., Ruthven, K., Mercer, N., Hofmann, R., Billingsley, F. R. B., \& Luthman, S. (2016). Developing teaching with an explicit focus on scientific thinking. School Science Review, 97(361), 75-85.

Vasilyeva, N.A. (2008). Development of Natural Science Education in Russia in the 18th-First Half of the 19th Century. (Before the Reforms of the 60s.) (Doctoral dissertation, Chelyabinsk, 2008).

Zimmerman, C., \& Klahr, D. (2018). Development of scientific thinking. Stevens' handbook of experimental psychology and cognitive neuroscience, 4 , $1-25$. 